\title{
Smad6 inhibits BMP/Smad1 signaling by specifically competing with the Smad4 tumor suppressor
}

\author{
Akiko Hata, 1,3 Giorgio Lagna, 2,3 Joan Massagué, 1,4 and Ali Hemmati-Brivanlou, ${ }^{2,4}$ \\ ${ }^{1}$ Cell Biology Program, Howard Hughes Medical Institute and The Sloan-Kettering Division of the Cornell University \\ Graduate School of Medical Sciences, M emorial Sloan-Kettering Cancer Center; ${ }^{2}$ Laboratory of M olecular Embryology, The \\ Rockefeller University, N ew York, NY 10021
}

\begin{abstract}
Bone morphogenetic protein (BMP) receptors signal by phosphorylating Smad1, which then associates with Smad4; this complex moves into the nucleus and activates transcription. Here we report the existence of a natural inhibitor of this process, Smad6, a longer version of the previously reported JV15-1. In Xenopus embryos and in mammalian cells, Smad6 specifically blocks signaling by the BMP/Smad1 pathway. Smad6 inhibits BMP/Smad1 signaling without interfering with receptor-mediated phosphorylation of Smad1. Smad6 specifically competes with Smad4 for binding to receptor-activated Smadl, yieding an apparently inactive Smad1-Smad6 complex. Therefore, Smad6 selectively antagonizes BMP-activated Smad1 by acting as a Smad4 decoy.
\end{abstract}

[Key Words: Smad proteins; BMP receptors; TGF $\beta$; Xenopus; antagonist; mammalian cells]

Received October 3, 1997; revised version accepted N ovember 19, 1997.

Members of the transforming growth factor $\beta$ (TGF $\beta$ ) family of cytokines, which also includes activins and the bone morphogenetic proteins (BMPs), initiate signaling from the cell surface by interacting with two distinct serine/threonine kinase receptors (Massagué and WeisGarcia 1996; ten Dijke et al. 1996). Ligand binding induces the formation of a complex in which the type II receptor phosphorylates and activates the type I receptor; this protein then propagates the signal by phosphorylating a family of signal transducers, the Smad proteins (Massagué et al. 1997). To date, eight vertebrate Smad proteins, Smad1-Smad-7 and Smad-9, are cloned (Massagué et al. 1997; Topper et al. 1997; Watanabe et al. 1997). The members of this family have conserved amino- and carboxy-terminal domains, hereafter referred to as the $\mathrm{N}$-domain and the $\mathrm{C}$-domain. The $\mathrm{C}$-domain has effector function, as it participates in homomeric and heteromeric interactions (Hata et al. 1997; Shi et al. 1997; Wu et al. 1997) and acts as a transcriptional activator (Chen et al. 1996; Liu et al. 1996).

Although Smads display common structural features, recent studies have revealed that their functions in the signaling pathway are diverse and can be divided into three classes: (1) receptor-regulated Smad proteins, which act as direct substrates of the receptors; (2) Smads that act as functional partners of the receptor-regulated Smads; and (3) antagonistic Smads or anti-Smads.

\footnotetext{
${ }^{3}$ These authors contributed equally to this work. ${ }^{4}$ Corresponding authors.

E-MAIL j-massague@ski.mskcc.org FAX (212) 717-3298. E-MAIL brvnlou@ rockvax.rockefeller.ech; FAX (212) 327-8656.
}

Smad1, Smad2, Smad3, Smad5, and Smad9 bel ong to the first class: Smad 1 and presumably its closely related members Smad5 and Smad9 mediate BMP signaling (Graff et al. 1996; Hoodless et al. 1996; Lechleider et al. 1996; Liu et al. 1996; Thomsen 1996; Yingling et al. 1996; Kretzschmar et al. 1997; Suzuki et al. 1997; Watanabe et al. 1997) whereas Smad2 and Smad3 mediate TGF $\beta$ /activin signaling (Baker and $\mathrm{H}$ arland 1996; Eppert et al. 1996; Graff et al. 1996; Macias-Silva et al. 1996; Zhang et al. 1996). These Smads are directly phosphorylated on serine residues at their carboxy-terminal ends (SSXS motif) by the specific type I receptor (M acias-Silva et al. 1996; Kretzschmar et al. 1997), and their phosphorylation leads to formation of a heteromeric complex with the second Smad class, which includes Smad4 in vertebrates (Lagna et al. 1996; Zhang et al. 1997). Unlike receptor-regulated Smads, which are specific for each pathway, the tumor suppressor Smad4/DPC4 (Hahn et al. 1996) acts as a shared partner for both BM P-specific and TGF $\beta$ /activin-specific Smads (Lagna et al. 1996; Zhang et al. 1997) and plays an essential role as a transcriptional activator in the nucleus (Liu et al. 1997).

Recently, a third class of Smads has been reported, whose members act as antagonists of these signaling pathways (Hayashi et al. 1997; Imamura et al. 1997; N akao et al. 1997; Topper et al. 1997; Tsuneizumi et al. 1997). When overexpressed, these Smads can interact with various type I receptors and nonselectively inhibit signaling by various TGF $\beta$ superfamily members, leading to the notion that antagonistic Smads act as general blockers of type I receptors (Hayashi et al. 1997; Imamura et al. 1997; N akao et al. 1997). In contrast to 
this model, the results presented here show that both in Xenopus and in mammalian cells, Smad6 efficiently blocks Smad1 signaling, without inhibiting Smad2 signaling. Consistently, we observe a direct, BMP-dependent interaction of Smad6 with Smad1, but not with Smad2 or Smad4. The Smad1-Smad6 interaction can prevent the formation of the Smad1-Smad4 complex, which is required for BM P signaling. Although Smad6 can associate with type I receptors, it does so indiscriminately and inhibits Smadl signaling without inhibiting receptor-mediated phosphorylation. Thus, we conclude that Smad6 inhibits BMP/Smadl signaling in vivo by acting as a selective Smad4 decoy.

\section{Results}

\section{Smad6 structure}

Smad6 (originally known as JV15-1) was previously reported to bea 235-amino-aci d protein encoded by various human EST clones (Riggins et al. 1997). By screening a human T-cell cDNA library with a probe corresponding to the Smad6 C-domain, we isol ated a cDN A encoding a 496-amino-acid protein (Fig. 1A) with a typical fulllength Smad domain structure (Fig. 1B). The screening of a Xenopus library yielded partial CDN A clones encoding products that were $>67 \%$ identical to the last 276 amino acids of the human Smad6 sequence. Smad6 is more closely related to Smad7 (40\% identity; Fig. 1A) than to other Smads (17\%-19\% identity; Fig. 1B). Smad6 lacks the carboxy-terminal SSXS motif that serves as a receptor phosphorylation site in receptor-regulated Smads (Macias-Silva et al. 1996; Kretzschmar et al. 1997) and lacks an additional portion at the carboxyl terminus that is highly conserved in other Smads (Fig. 1C).

Smad6 RNA injection causes formation of ectopic dorsal axes in Xenopus embryos

Whole-mount in situ hybridization of Xenopus embryos at gastrula, neurula, and tadpole stages with a Xenopus Smad6 probe revealed a generalized pattern of Smad6 expression in all stages (data not shown). To begin to address the function of Smad6 in vivo, RNA encoding human Smad6 was coinjected with $\beta$-galactosidase RNA, used as lineage tracer, into the ventral vegetal blastomeres of eight cell stage embryos. Embryos injected with these transcripts, devel op a secondary dorsal axis in $>90 \%$ of the cases ( $n=30$; Fig. $2 A$ ). Injection of greater amounts of Smad6 induced secondary axes that were proportionally more complete (Fig. 2A, top right). Furthermore, $\beta$-gal staining of the injected embryos revealed that the progeny of the injected blastomere directly contributed to the ectopic axis, suggesting an organizer type of activity mediated by Smad6 (Fig. 2A). As with other Smad C-domains (Baker and Harland 1996; Liu et al. 1996), constructs encoding the isolated C-domain of Smad6 (human or Xenopus) were more potent than full-length Smad6 at generating this phenotype (data not shown).
Control injections of Smad6 in the dorsal marginal zone produced embryos with enhanced head structures but with a normal primary axis, suggesting the inability of Smad6 to interfere with dorsal mesoderm formation (Fig. 2B). Theinjection of RN A s encoding activin (Thomsen et al. 1990), inhibitors of the BM $P$ pathway, such as Noggin (Smith and Harland 1992), Chordin (Sasai et al. 1994), Follistatin (Hemmati-Brivanl ou et al. 1994; Sasai et al. 1995), or the dominant-negative type I BM P receptor (tBM PR-I) (Graff et al. 1994; Suzuki et al. 1994), can give rise to a similar secondary axis phenotype. Overexpression of Smad2 has the same effect [Fig. 2C (Baker and Harland 1996; Graff et al. 1996)]. In this assay, coinjection of Smad2 and Smad6 produces secondary axes that are more frequent and extend more anteriorly than those obtained by injection of either Smad al one at the chosen concentrations (Fig. 2C), suggesting an additive effect. The results obtained with Smad6 are therefore consistent with either activation of the activin pathway or inhibition of BMP signaling.

\section{Smad6 inhibits BMP signaling and neuralizes ectodermal explants}

To differentiate between the two possibilities described above, we took advantage of the ectodermal explant (animal cap) assay. When removed at blastula stages and cultured in saline solution, animal caps develop as epidermis. This is the result of endogenous BMP signaling that induces and maintains the epidermal fate within the explants. Any interference with this signaling pathway unveils the "default" fate of the ectoderm and the cells switch their fate to neural (Wilson and Hemmati-Brivanlou 1997). Animal caps incubated with activin protein, on the other hand, devel op as mesoderm (A sashima et al. 1990; Smith et al. 1990; Thomsen et al. 1990; van den Eijnden-Van Raaij et al. 1990). Therefore, the animal cap assay offers an easy way to distinguish between an effect of Smad6 that is due to the activation of the activin pathway versus an interference with the BMP pathway.

Embryos were injected with either control RNA or transcripts encoding full-length Smad6 or its C-domain in the animal pole. Animal caps were removed at blastula stage and allowed to devel op until controls reached tailbud stages, at which time they were assayed by reverse transcription (RT)-PCR for cell fate choices. Figure 2D shows that overexpression of Smad6 or Smad6 Cdomain (amino acids 272-496) leads to the induction of NRP-1, a pan-neural marker, and XAG-1, a marker of cement gl and (an organ associated with neural tissue in Xenopus). Interestingly, Iow levels of full-length Smad6 $(0.5 \mathrm{ng})$ induced mostly cement gland, whereas a higher dose (4 ng) also induced neural tissue efficiently. A similar dose-dependent effect has also been observed for $\mathrm{N}$ oggin and tBMPR-IA and is thought to reflect a gradual inhibition of the morphogen-like action of the BMPS (Wilson et al. 1997). Importantly, no expression of the axial mesodermal marker muscle actin was detected (Fig. 2D), indicating that induction of neural tissue is direct. Furthermore, coinjection of Smad6 inhibited the 
Hata et al.

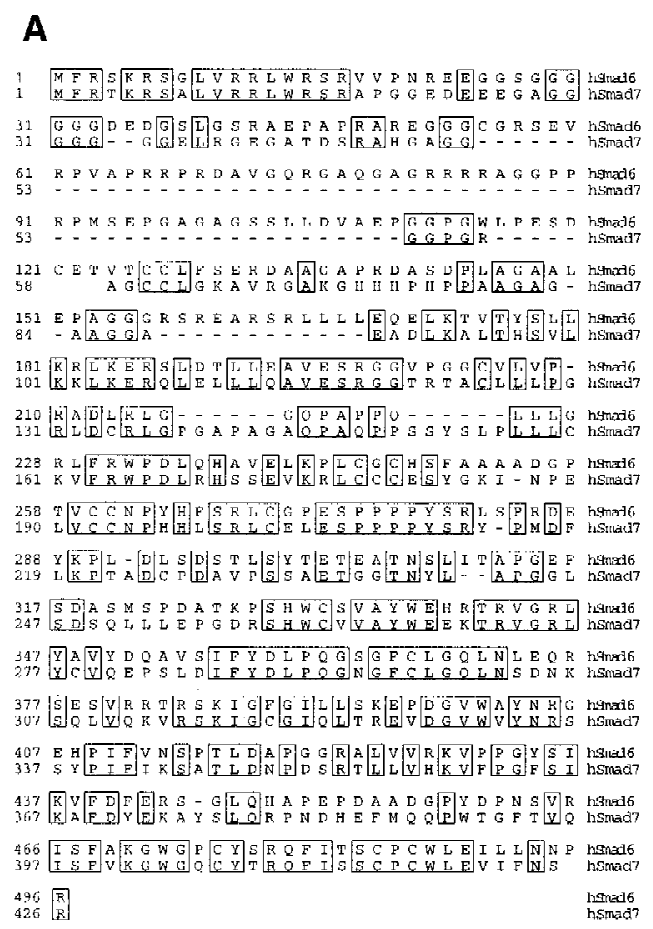

B
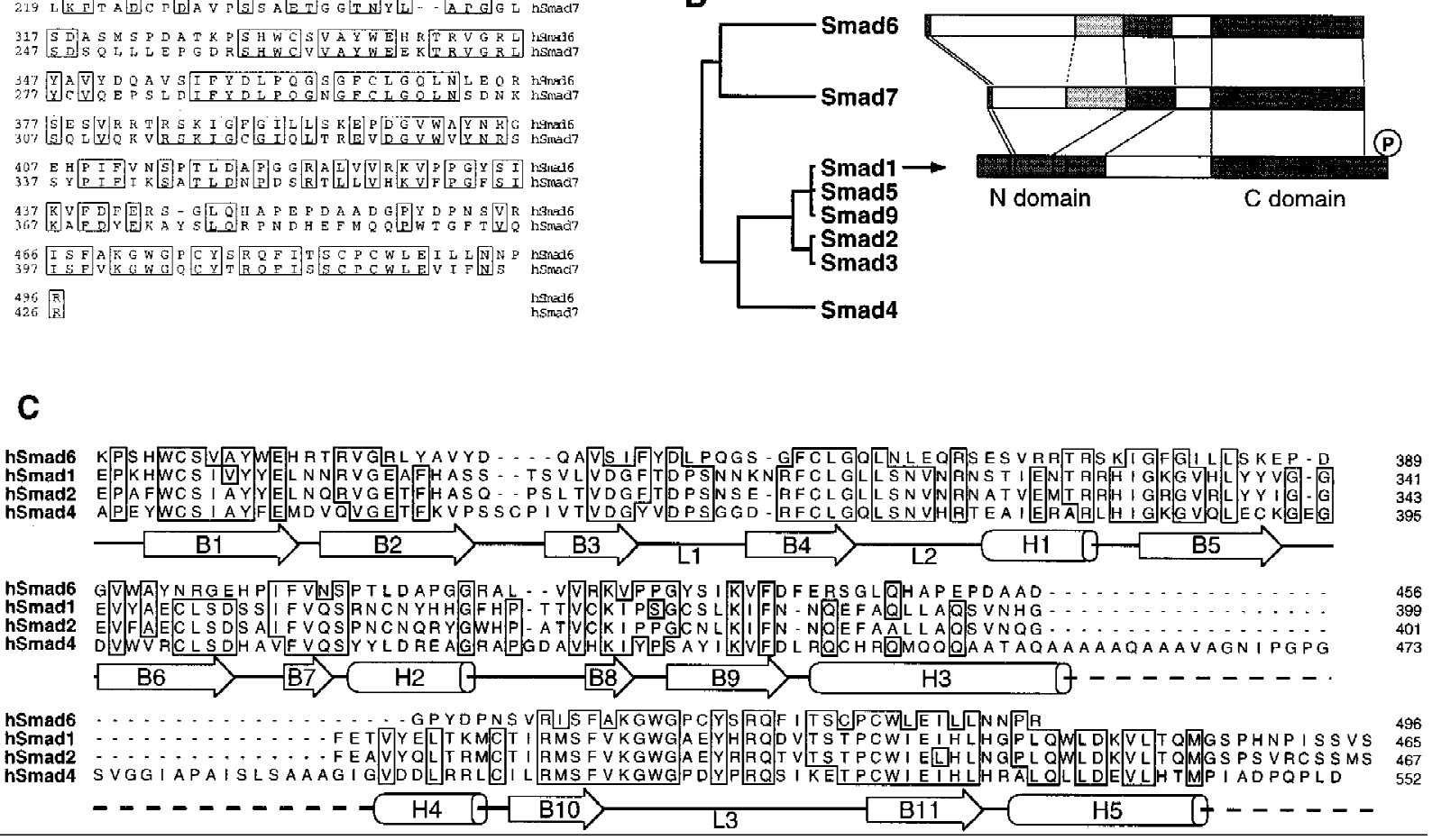

Figure 1. Structure of Smad6. (A) Alignment of the predicted amino acid sequence of human Smad6 and Smad7. Identical residues are boxed. (B) Smad homology tree and schematic comparison of the structures of Smad6, Smad7, and Smad1. The amino and carboxy-terminal homologous regions ( $\mathrm{N}$ - and C-domain) are darkly shaded. A region conserved only between Smad6 and Smad7 is lightly shaded. (C) Alignment of C-domain sequences of Smad6 and other Smads, indicating the secondary structure elements of the Smad4 C-domain (Shi et al. 1997). In the crystal structure of Smad4 this region forms an $\alpha$-helix ( $\alpha$-helix 5) that associates with $\alpha$-helices 3 and 4 in a three-helix bundle. This structure contributes the formation of a Smad 4 homotrimer by interacting with loops 1 and 2 of the adjacent monomer. The region corresponding to loops 1 and 2 in Smad6 is also very divergent from Smad4 and the receptor-regulated Smads. However, most of the components that constitute the $\beta$-sandwich core structure of the Smad4 C-domain are conserved in Smad6.

induction of the ventral mesoderm marker globin by the constitutively active BMP type I receptor BMPR-IB(QD) (Fig. 2E; Kretzschmar et al. 1997). These results strongly suggest that Smad6 acts as an antagonist of BM P signaling rather than as a mediator of activin signaling.

\section{Smad6 is an inhibitor of BMP/Smad1 signaling}

To determine whether Smad6 might be an inhibitor of BM P signals mediated by Smad1, we tested the effects of the corresponding transcripts, alone or in combination, on the induction of ventral mesoderm markers in the animal cap assay. Overexpression of Smad6 al one inhibited the basal level of expression of Xvent-1 and Xhox-3 (Fig. 3A). Induction of these two markers is known to require endogenous BMP signals mediated by Smad1 (Lagna et al. 1996; Liu et al. 1996; Thomsen 1996). Furthermore, Smad6 potently inhibited the overinduction of these markers by coinjected Smad1 (Fig. 3A). Smad6 inhibited Smadl signaling specifically, as it did not inter- 
A

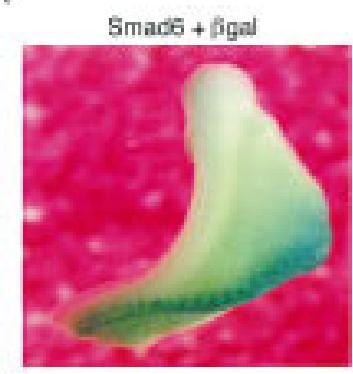

B

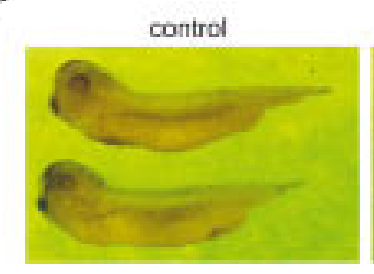

C

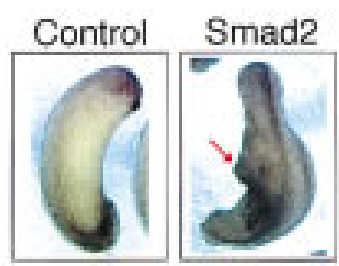

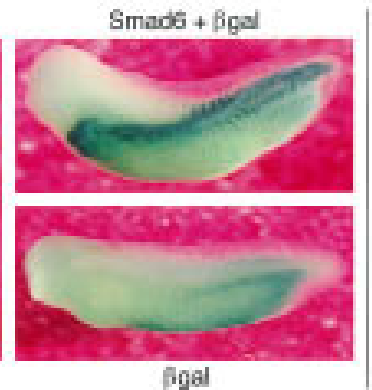

maz
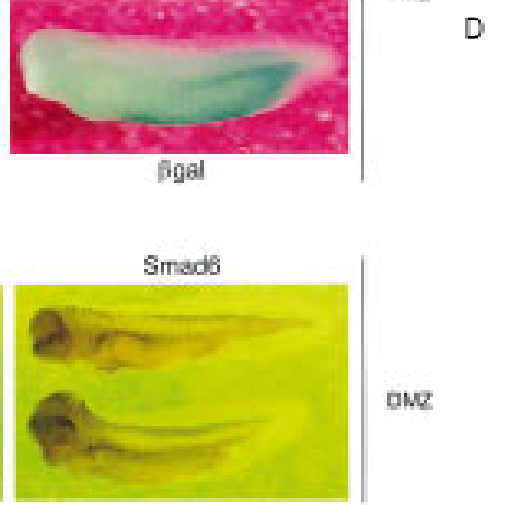

E

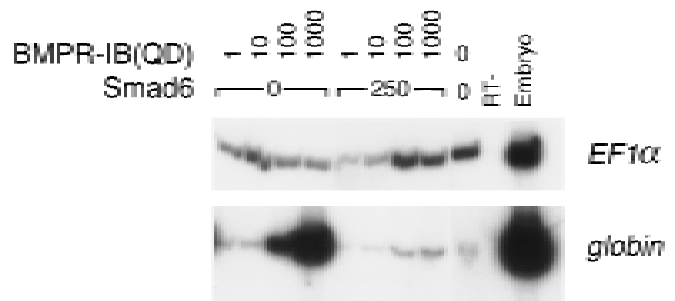

Figure 2. Smad6 induces secondary axes and neuralizes ectoderm in Xenopus. (A) Smad6 overexpression induces the formation of a secondary axis. Smad6 RNA (0.5-4 ng) was coinjected with nuclear $\beta$-galactosidase ( $\beta$-gal)RNA (100 pg) into the ventral vegetal blastomeres of eight cell stage embryos. Unlike control embryos injected with $\beta$-gal al one (bottom right), Smad6 coinjected embryos develop an ectopic dorsal axis (left and top right). $\beta$-Galactosidase staining of the injected embryos reveals that the progeny of the injected blastomere di rectly contri bute to the ectopic axis. Dorsal at left; anterior at top. Lateral at right; anterior at left. (B) Smad6 does not affect formation of the primary dorsal axis. Smad6 RN A (1-4 ng) was injected into the dorsal marginal zone of four cell stage embryos. Compared to control embryos (left panel), Smad6-injected tadpoles display enlarged heads and cyclopia, but have normal body axes (right). (C) Secondary axis formation by the activin signaling molecule Smad2 is enhanced by coinjection of Smad6. Smad2 RN A (1 ng), Smad6 RN A (1 ng), or both RN As (1 ng each) were injected into ventral vegetal blastomeres of eight cell stage embryos. Coinjection of Smad2 and Smad6 produces secondary axes (red arrows) that are more complete than those obtained by injection of either Smad al one. Anterior is at top. (D) Smad6 neuralizes ectodermal explants. Smad6 and Smad6 C-domain RN As were injected at the indicated amount in the animal pole of two-cell stage embryos. At the blastula stage, animal caps were dissected and cultured in saline solution. At the tailbud stages (stage 22), total RN A was harvested and analyzed by RT-PCR for the presence of the indicated transcripts. Full-length human Smad6 (0.5 and 4 ng) induces NRP-1, a pan-neural marker, and XAG-1, a marker of cement gland. Cement gland is induced efficiently even at the lower dose; induction of neural tissue requires a higher dose of Smad6. The isolated C-domain RNA is a more potent inducer of both XAG-1 and NRP-1 than full-length Smad6. N either construct induced muscle actin, a marker of dorsal (paraxial) mesoderm. EF-1 $\alpha$, ubiquitously expressed, is a loading control. RNA from whole embryos (Embryo) provides the positive control. The RT lane is identical to the embryo lane, except that reverse transcriptase was omitted. (E) Smad6 interferes with blood induction by a constitutively active BM P receptor. BMPR-IB(QD) RN A (1-1000 pg) was injected either al one or together with Smad6 RN A (250 pg) in the animal pole. BMPR-IB(QD)-injected ectodermal explants show induction of gl obin at stage 30, and this response is blocked by coexpressed Smad6.

fere with the induction of a general mesoderm marker (brachyury) or a dorsal mesoderm marker (goosecoid) by the activin mediator Smad2 (Fig. 3A; Baker and Harland 1996; Graff et al. 1996). Consi stently, Smad6 was unable to inhibit the induction of muscle actin in animal caps incubated with activin (data not shown).

To investigate the action of Smad6 in a mammalian cell system, we determined the effect of Smad6 on transcriptional activation by Smad1 and Smad2. In R-1B/L17 mink lung epithelial cells, full-length Smad1 or Smad2 fused to the DNA-binding domain of GAL4 activates transcription of a GAL4 reporter gene in response to BM P2/ 4 or TGF $\beta$ signals, respectively (Fig. 3B; Liu et al. 1996). This activity requires the presence of Smad4 in the cell (Liu et al. 1997). Cotransfection of Smad6 completely abolished the activation of GAL4-Smad1 by BM P2 but did not affect the activation of GAL4-Smad2 by TGF $\beta$ (Fig. 3B). M oreover, a GAL4-Smad6 C-domain fusion protein was unable to activate transcription in this assay (data not shown). We al so tested the activation 
Figure 3. Smad6 specifically inhibits the BM P/Smad1 signaling pathway. (A) Smad6 blocks induction of ventral mesoderm by Smad1 but not induction of dorsal mesoderm by Smad2. An increasing amount of Smad6 RN A (0.5-4 ng) was coinjected with or without a fixed amount of Smadl or Smad2 RNA (2 ng). Animal caps from injected embryos were collected at gastrula stage (stage 11.5) and subjected to RT-PCR. Xvent- 1 and Xhox-3 are markers of ventral mesoderm; goosecoid is a dorsal mesoderm marker and brachyury is a pan-mesodermal marker. (B) BM P-dependent transcriptional activation of GAL4-Smadl fusion protein is blocked by Smad6. R-1B/L17 cells were transfected with the reporter gene (GIE1BCAT, $1 \mu \mathrm{g})$, appropriate receptors (T $\beta$ R-I for TGF $\beta$ or BM PR-IB and BMPR-II for BMP2), and either a vector containing the GAL4 DNA-binding domain (DBD) alone or fusion constructs of DBD with Smad1 or Smad2 in the presence or absence of Smad6 $(2 \mu \mathrm{g})$. Cells were incubated with or without 5 nM BMP2 (B) or 100 pM TGF $\beta$ (T) for $18 \mathrm{hr}$. CAT activity is expressed as the mean \pm S.D. of three independent experiments. (C) TGF $\beta$ or activin-induced transcriptional activation of the 3TP promoter is not inhibited by Smad6. R-1B/L17 cells were transfected with the reporter gene (p3TP-lux) and type I receptors for TGF $\beta$ (T $\beta$ R-I) or activin (ActR-IB) and were treated with or without 100 pM TGF $\beta$ (top) or $2 \mathrm{~nm}$ activin (bottom) for $18 \mathrm{hr}$. The ratios of stimulated to unstimulated levels of luciferase activity are indicated numerically, and their quotients plotted in the bar graph. Data are the mean \pm S.D. of triplicate values. N otice that although Smad6 transfection decreased the basal as well as the agonist-induced levels of luciferase activity, it did not decrease the relative induction by TGF $\beta$ or activin.

of the p3TP-lux reporter, which contains TGF $\beta$ /activin responsi ve elements from the PAI-1 promoter. Transient transfection of p3TP-lux into L17/R1B cells, together with the type I receptor T $\beta R-I$ or ActR-IB, generated a strong induction of p3TP-lux activity in response to TGF $\beta$ or activin (Fig. 3C). Doses of Smad6 vector well above those that inhi bited BM P signaling in this cell line (see Fig. 3B) did not diminish the induction of 3T P-lux by TGF $\beta$ or activin. Therefore, both in Xenopus embryos and in mammalian cells, Smad6 selectively inhibited BMP and Smadl signaling.

\section{Nonselective interaction with type I receptors}

To determine whether Smad6 might selectively interfere with the BMP/Smadl signaling pathway at the level of the BMP receptors, we cotransfected Smad6 constructs with wild-type or constitutively active forms of various type I receptors into COS cells, and analyzed the interaction of Smad6 with these receptors. When overexpressed in mammalian cells, both the full-length Smad6 (Fig. 4A) and the Smad6 C-domain (data not shown) can interact with the BM P type I receptor BM PR-IB, and the interaction is somewhat stronger with the hyperactive mutant BM PR-IB(QD). Smad6 al so bound to the kinasedeficient BMPR-IB receptor [BMPR-IB(KR), data not shown]. However, an interaction was detected also with

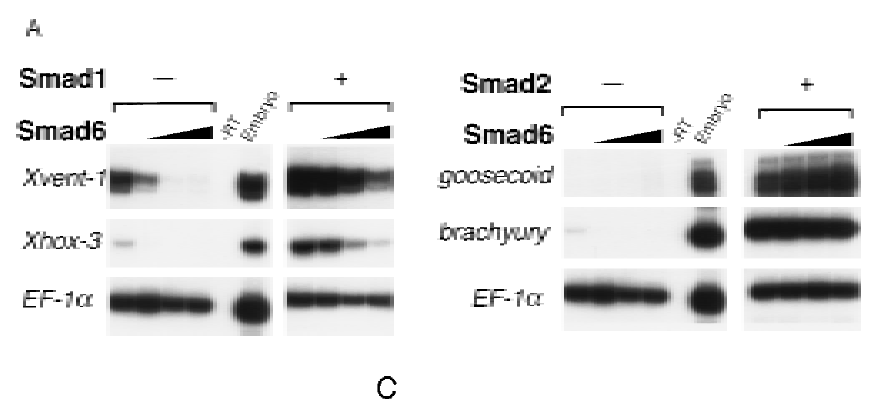

B
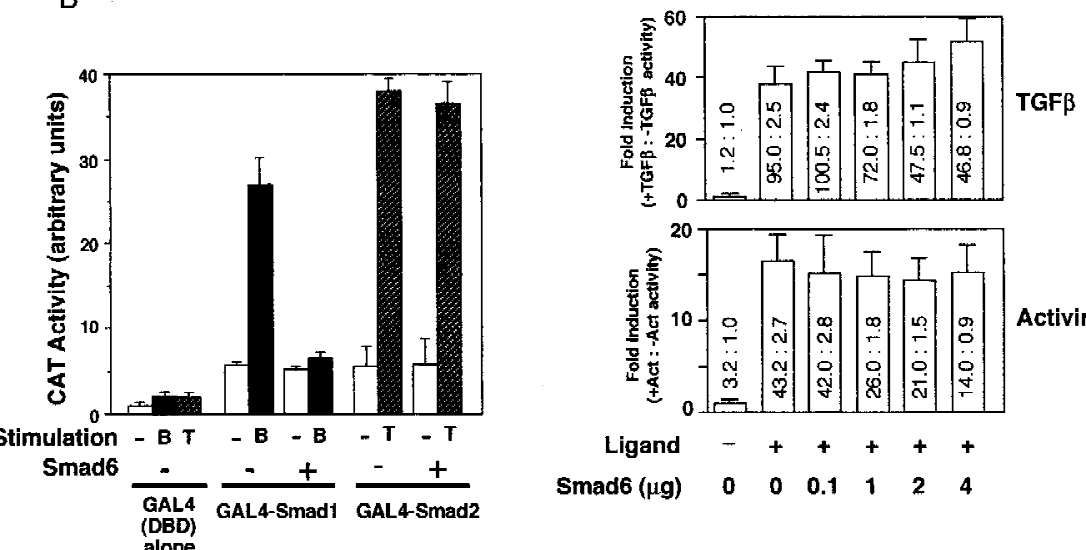

Ligand -+++++

Smad6 $(\mu \mathrm{g}) \quad 0 \quad 000.1 \quad 1 \quad 2 \quad 4$ the TGF $\beta$ type I receptor T $\beta R-I$ and the activin type I receptor ActR-IB and their respective activated forms, T $\beta R$-I(TD) (Wieser et al. 1995) and ActR-IB(TD) (Attisano et al. 1996) (Fig. 4A). Smad6 is a phosphoprotein, but in contrast to Smad1 and Smad2 (Eppert et al. 1996; Hoodless et al. 1996; Macias-Silva et al. 1996; Kretzschmar et al. 1997) its phosphorylation level was not increased in response to TGF $\beta$ or BMP (Fig. 4B). Thus, Smad6 appears to interact with type I receptors nonselectively.

\section{Smad6 inhibits signaling downstream of BMP receptors}

Expression of truncated BM P type I receptor constructs induces expression of neural markers in Xenopus ectodermal explants by inhibiting the antineuralizing activity of endogenous BMP (Graff et al. 1994; Suzuki et al. 1994; Xu et al. 1995). This dominant-negative effect can be reversed by overexpression of Smad1 (Graff et al. 1996; Thomsen 1996). It is thought that under these conditions, BMP signaling is restored in a BMP receptorindependent manner through the basal activity of the overexpressed Smad1 (Graff et al. 1996; Thomsen 1996). We tested whether Smad6 would inhibit Smadl signaling under these conditions. An ability of Smad6 to inhibit receptor-independent Smadl signaling would sug- 
A

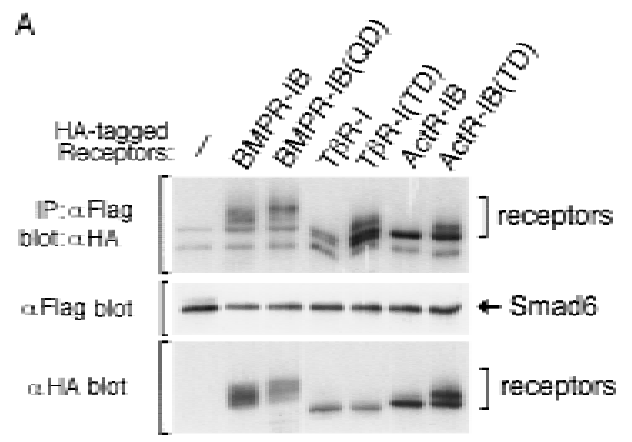

B
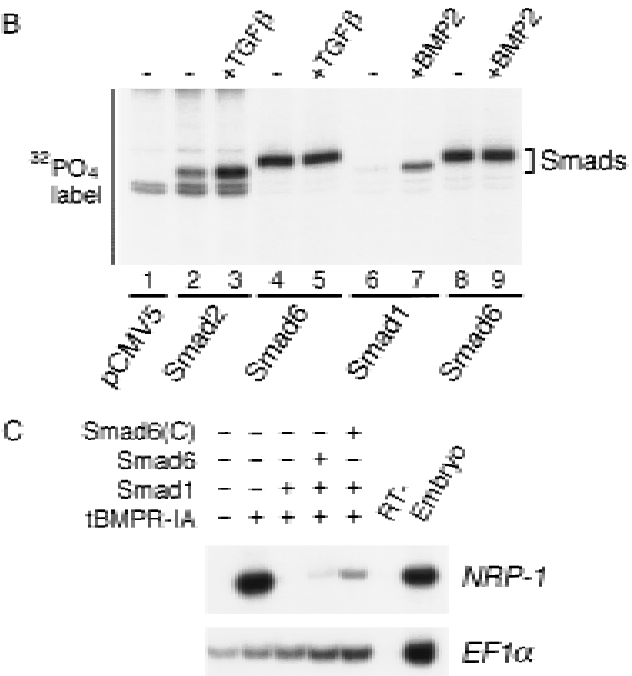

Figure 4. Smad6 is a phosphoprotein which binds to type I receptors nonspecifically and inhibits downstream of BM $P$ receptors. (A) Smad6 nonspecifically interacts with type I receptors of the TGF $\beta$ superfamily. COS cells were transfected with Flag-tagged Smad6 and HA-tagged wild-type or constitutively active type I receptor (QD and TD) for BM Ps (BM PR-IB), TGF $\beta$ $(T \beta R-I)$, or activins (ActR-IB). Cell lysates were subjected to anti-Flag immunoprecipitation using a monoclonal antibody followed by immunoblotting using anti-HA polyclonal antibody (toppanel). Immunoprecipitates of cells transfected with receptor alone did not contain specific proteins (data not shown). Similar levels of Smad6 and receptor expression were confirmed by analyzing aliquots of total cell lysate by SDSPAGE followed by immunoblotting (middle and bottom panels). (B) The level of phosphorylation of Smad6 is unchanged by BMP2 or TGF $\beta$ stimulation. R-1B/L17 cells were transiently transfected with an empty vector (pCMV5) or with the Flagtagged Smads indicated at the bottom. Smad2- or Smad6-transfected cells (lanes 2-5) were cotransfected with T $\beta$ R-I; Smad1or Smad6-transfected cells (lanes 6-9) were cotransfected with BM PR-IB and BM PR-II. Cells were labeled with [22 P]phosphate, stimulated with $(+)$ or without $(\rightarrow 100$ pM TGF $\beta$ or 5 nM BMP2 for $20 \mathrm{~min}$. Flag-tagged Smads were purified by immunoprecipitation with anti-Flag M 2 antibody and analyzed by SDS-PAGE and autoradiography. (C) Smad6 inhibits receptor-independent Smad1 signaling. Expression of dominant-negative BM P type I receptor (tBM PR-IA, 1 ng of RN A) induces neural tissue (NRP-1 marker) in Xenopus animal caps. Smadl (1 ng of RN A) prevents neural ization when coexpressed with tBM PR-IA, but its activity is inhibited by Smad6 and Smad6(C) (2 ng of RN A). EFl $\alpha$ is the loading control. gest that Smad6 acts downstream of BM P receptors. Fig ure $4 \mathrm{C}$ shows that coexpression of Smad6 or Smad6(C) blocked the antineuralizing effect of Smad1. Thus, although Smad6 interacts nonspecifically with type I receptors, it appears to inhibit the BM P/Smad1 pathway at a level downstream of the receptor.

Smad6 specifically associates with Smad1 in response to BMP

Because Smad6 inhibits downstream of the receptor, we searched for evidence of a specific mechanism at the level of Smad-Smad interactions. T o this end, Smad constructs tagged at the amino terminus with the flag epitope were cotransfected with Smad6 tagged at the amino terminus with $\mathrm{HA}$, and interactions between these proteins were investi gated in the presence or absence of agonists. Figure 5A (top panel) shows that Smad6 associated with itself in a ligand-independent fashion. In addition, Smad6 associated with Smad1 in response to BM P2 but not in response to TGF $\beta$, and finally, Smad6 did not interact with $\mathrm{Smad} 2$ or Smad4 in response to either BM P2 or TGF $\beta$.

In parallel assays, the Smad6 C-domain associated constitutively with Smad1, and this interaction was somewhat increased in response to BM P2 but not in response to TGF $\beta$. However, no association was observed between the Smad6 $\mathrm{C}$-domain and either Smad2 or Smad4 (Fig. 5A, bottom panel). The specificity of the Smad6-Smad1 association and the direct nature of this interaction were demonstrated by use of a yeast twohybrid system. Using this approach, we have previously shown that the homo- and hetero-oligomeric interactions of Smad2 and Smad4 are mediated by their C-domains (Hata et al. 1997). A LexA-Smad6 C-domain fusion protein was used as bait. Although the $C$-domain of Smad6 was able to interact with another Smad6 C-domain or with the Smadl C-domain, it did not interact with the C-domains of Smad2 or Smad4 (Fig. 5B). This suggests that Smad6 and Smad1 can interact directly and specifically with each other in a BM P-dependent fashion.

Smad6 competitively inhibits formation of the Smad1-Smad4 complex

The properties of the Smad6-Smad1 interaction described above are very similar to those of the Smad4Smadl interaction. In both cases, the interaction be tween the full-length proteins is dependent on BMP stimulation (Lagna et al. 1996) and the interaction by the C-domains is constitutive (Hata et al . 1997; A. Hata and J. Massagué, unpubl.). A major difference is that Smad4 can interact with different receptor-activated Smads (Lagna et al. 1996; Zhang et al. 1997), whereas Smad6 interacts with receptor-activated Smad1 but not receptor-activated Smad2. These observations not only suggested that Smad1 is the specific target of Smad6 but al so raised the possibility that Smad6 might act by competing with Smad4 for receptor-activated Smad1.

To test this hypothesis, we determined the effect of 
A

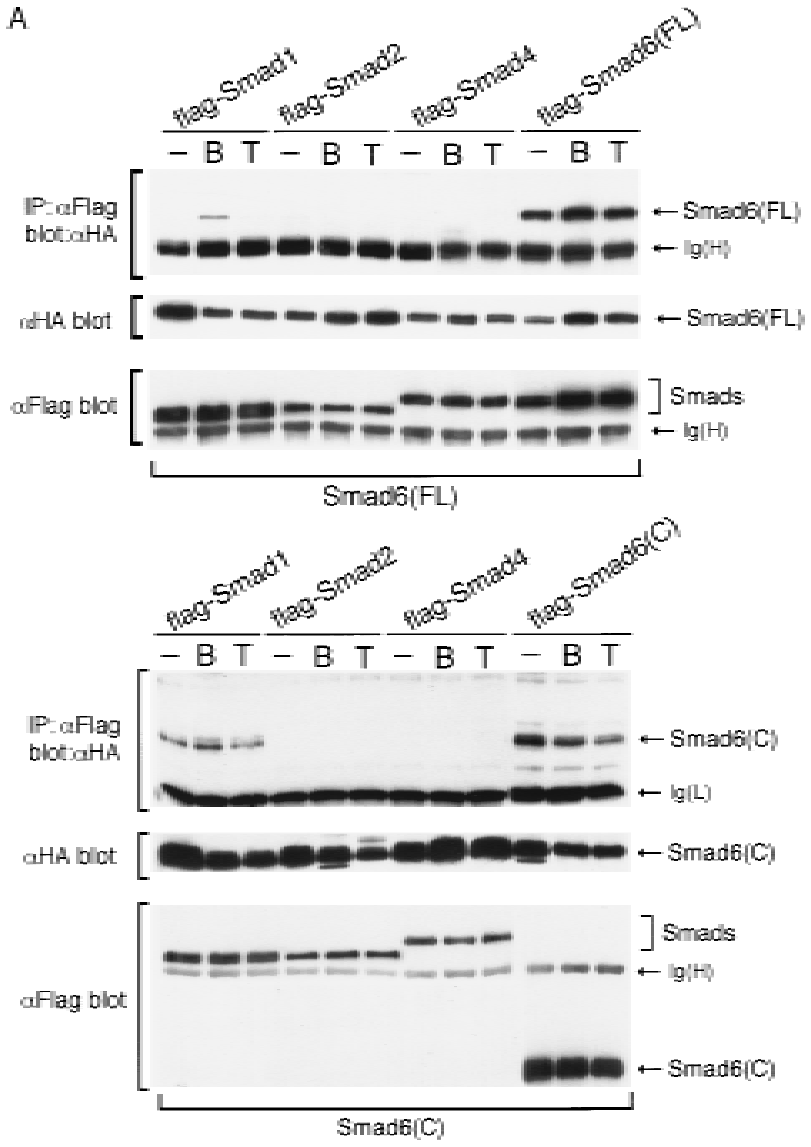

日

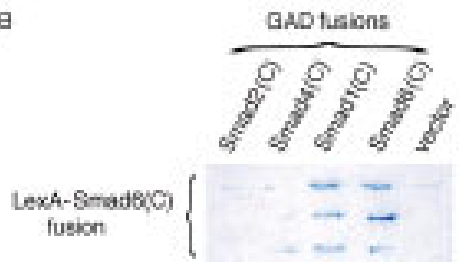

Figure 5. Smad6 interact with itself and Smad1, but not with Smad2 or Smad4. (A) Specific interaction between Smad1 and Smad6. COS cells were transiently transfected with Flag-tagged Smads as indicated on the top, and HA-tagged Smad6 (toppanel) or Smad6 C-domain (bottom panel). Cells were treated with 5 nм BM P2 or 100 pM TGF $\beta$ for $1 \mathrm{hr}$ before harvest. Cell lysates were subjected to immunoprecipitation with anti-Flag antibody and then immunoblotting using the anti-HA monoclonal antibody 12CA5. Expression of Smads was measured by anti-Flag or anti-HA immunoprecipitation of aliquots of cell lysates, followed by anti-Flag or anti-HA immunoblotting (bottompanel). $[\operatorname{Ig}(\mathrm{H})$ and $\mathrm{Ig}(\mathrm{L})] \mathrm{Immunoglobulin}$ heavy and light chain bands, respectively. (B) The interaction between Smad6 C-domain and Smad1 C-domain is specific and direct. The C-domains of Smad1, Smad2, Smad4, and Smad6 fused to the GAL4 activation domain (GAD) were tested for interaction with Smad6 Cdomain fused to the LexA DNA-binding domain in yeast. Interaction was monitored by the $\beta$-galactosidase assay, which allowed us to score for association by the presence of blue color.

Smad6 on Smad1-Smad4 associ ati on. Smad6 overexpression completely inhibited the formation of a Smad1-
Smad4 compl ex in response to BM P2 (Fig. 6A, top panel). Importantly, concentrations of Smad6 that completely inhibited formation of the Smad1-Smad4 complex in re sponse to BM P2 did not inhibit the BM P2-induced phosphorylation of Smadl (Fig. 6A, bottom panel). We did observe an inhibition of Smad1 phosphorylation by Smad6, but only when the Smad6-Smad1 concentration ratio was 10-fold higher than the highest ratio used in Figure 6A (data not shown).

To determine more directly whether Smad6 and Smad4 compete for receptor-activated Smad1, we cotransfected HA epitope-tagged versions of full-length Smad4 and the Smad6 C-domain together with flag epitope-tagged Smad1. In the absence of BM P stimulation, the constitutive association of Smad1 with Smad6 Cdomain described above was not inhibited by Smad4 (Fig. $6 \mathrm{~B}$, left). However, upon stimulation with BMP2, increasing concentrations of Smad4 progressively associated with Smad1 displacing the Smad6 C-domain from the complex (Fig. 6B, right). In accordance with this observation, inhibition of BM P2-induced GAL4-Smad1 activation by Smad 6 was rescued by coexpressi on of Smad4 (Fig. 6C). Collectively, these results suggest that Smad6 acts not by inhibiting receptor activation of Smad1 but by competitively inhibiting the association of Smad4 with receptor-activated Smad1.

The inhibitory activity of Smad 6 segregates with its ability to interact with Smad1

To test further the mechanism of Smad6 action, we generated two Smad6 mutants, G471S and $\Delta 478$. Both mutations are located in the L3 loop, a region implicated in heteromeric Smad-Smad interactions and exposed to the surface in the Smad4 crystal structure (Shi et al. 1997). The G471S mutant corresponds to a point mutation found in Drosophila Mad (N ewfeld et al. 1996), whereas the $\Delta 478$ mutant is deleted of amino aci ds $478-496$ at the carboxyl terminus and is equival ent to a cancer mutation in Smad4/DPC4 (Hahn et al. 1996). The $\Delta 478 \mathrm{mu}-$ tant protein was unable to interact either with type I receptors for the TGF $\beta$ superfamily (Fig. 7A) or with Smad1 (Fig. 7B) and lost the ability to inhibit BMP-dependent GAL4-Smad1 activation (Fig. 7C). Importantly, the G471S mutant protein could still associate with type I receptors (Fig. 7A) but lacked the ability to interact with Smad1 (Fig. 7B) or to inhibit signaling (Fig. 7C). The failure of the G471S mutant to inhibit Smad1 responses while retaining its abi lity to bind receptors strongly supports a mechanism in which the inhibitory action of Smad6 is triggered not by a block at the receptor level but by a physical interaction with Smad1 that prevents formation of the Smad1-Smad4 heterocomplex.

\section{Discussion}

Smad6 as a selective antagonist of the BMP/Smad1 signaling pathway

Smad6 is a divergent member of the Smad family-its 

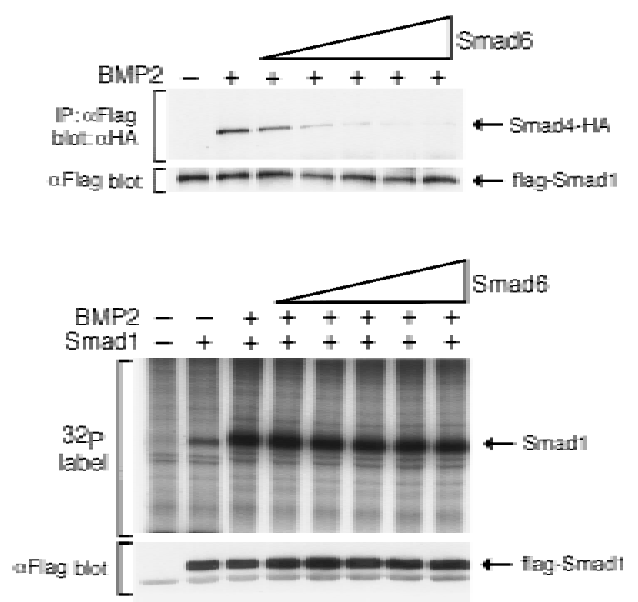

B

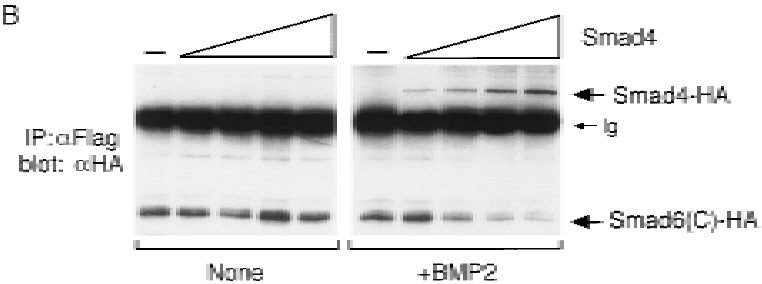

$\mathrm{C}$

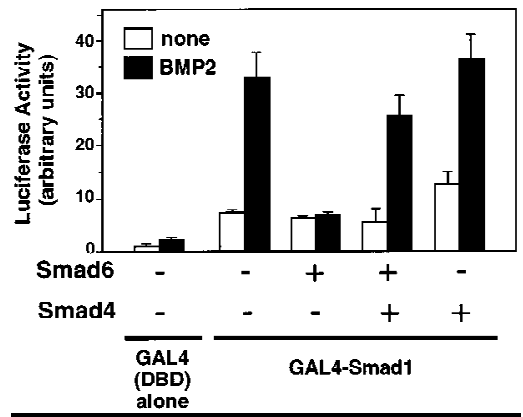

Figure 6. Smad6 inhibits the formation of the Smad1-Smad4 complex. (A) Smad6 inhibits the BM P-dependent complex formation between Smad1 and Smad4 but does not inhibit the BM P-dependent phosphorylation of Smad1. COS cells were transiently transfected with BMPRIB/BM PR-II $(0.1 \mu \mathrm{g})(B M P 2$ + lanes), Flag-tagged Smad1 $(1 \mu \mathrm{g})$, and increasing amount of Smad6 $(1,2.5,5,7.5$, and $10 \mu \mathrm{g})$. One-half of the cells was treated with 5 nM BM P2 for 30 min and harvested. Cell lysates were subjected to immunoprecipitation with anti-Flag $\mathrm{M} 2$ antibody followed by immunoblotting with anti-HA polyclonal antibody (Y-11) (top panel, IP; $\alpha$ Flag; blot, $\alpha \mathrm{HA}$ ). Expression of Smad1 was monitored by analyzing aliquots of total cell lysate by SDS-PAGE followed by immunoblotting with anti-Flag antibody (top panel, $\alpha$ Flag blot). The remaining half of the cells was labeled with [ ${ }^{32} \mathrm{P}$ ]phosphate, stimulated with $5 \mathrm{nM}$ BM P2 for $20 \mathrm{~min}$, and harvested. Cell lysates were subjected to immunoprecipitation with anti-Flag M 2 antibody and analyzed by SDS-PAGE and autoradiography (bottom panel, ${ }^{32} \mathrm{P}$ label). Expression of Smad1 was monitored by immunoprecipitation followed by immunoblotting using anti-Flag M2 antibody (bottom panel, $\alpha$ Flag blot). (B) Smad4 disrupts the formation of a complex between Smad1 and Smad6(C). COS cells were transiently transfected with Flag-tagged Smad1 $(2 \mu \mathrm{g})$, HA-tagged Smad6 C-domain $(2 \mu \mathrm{g})$, and increasing amounts of HA-tagged Smad4 $(1,2,4,8 \mu \mathrm{g})$. Cells in the right panel were treated with $5 \mathrm{nM} \mathrm{BM} \mathrm{P2} \mathrm{for} 1 \mathrm{hr}$ before harvest. Cell lysates were subjected to immunopreci pitation with anti-Flag M 2 antibody followed by immunoblotting using anti-HA monoclonal antibody (12CA5). The migration of Smad6 C-domain and Smad4 proteins is indicated at right. Increasing doses of Smad4 do not affect Smad1-Smad6(C) complex formation in the absence of BM P2 stimulation; however, in the presence of BM P2, formation of the Smad1-Smad4 complex inhibits Smad1-Smad6(C) complex formation. (C) Smad4 rescues the Smad6-induced inhibition of BM P-dependent Smad1 activation. R-1B/L17 cells were transfected with the reporter gene (GAL4-Iux, $1 \mu \mathrm{g})$, BM PR-IB (1 $\mu \mathrm{g})$, BM PR-II $(0.1 \mu \mathrm{g})$, and either a vector containing the GAL4 DN A binding domain (DBD) al one or a GAL4(DBD)-Smad1 fusion construct. Smad6 $(2 \mu \mathrm{g})$ and/ or Smad4 $(4 \mu \mathrm{g})$ were cotransfected where indicated. Cel Is were incubated with (solid bars) or without (open bars) $5 \mathrm{nmr}$ for $18 \mathrm{hr}$. Luciferase activity is expressed as the mean \pm S.D. of two independent experiments.

closest relative being Smad7. The human Smad6 cDN A clones isolated in the present study encode a protein with an overall domain structure typical of Smads. Most of the sequence elements that form the core $\beta$-sandwich in the crystal structure of the Smad4 C-domain (Shi et al . 1997) are discernible in the Smad6 C-domain. However, Smad6 lacks the carboxy-terminal SSXS receptor phosphorylation sequence found in receptor-regulated Smads (Macias-Silva et al. 1996; Kretzschmar et al. 1997), as well as a carboxy-terminal region, which participates in a three- $\alpha$-helix bundle in Smad4 that mediates homotrimeric interactions (Shi et al. 1997). Thus, the Smad6 C-domain may have an overall fold similar to that of Smad4 but may establish homo-oligomeric interactions through unique nonconserved regions.

The present results show that Smad6 can selectively antagonize the BMP/Smad1 signaling pathway. During development and in the adult, BMPs control many aspects of tissue formation and homeostasis (for review, see Hogan 1996), and regulation of BMP activity is of critical importance. In the extracellular space, BMP ac- tivity is inhibited by BM P-sequestering proteins including $\mathrm{N}$ oggin, Chordin, and Follistatin. The present study reveals that Smad6 is a member of a novel class of BM P pathway inhibitors operating intracellularly. Evidence for this is provided by experiments with Xenopus embryos. In the ectoderm of these vertebrates, BM P4 suppresses the differentiation of neural tissue and induces epidermal fate (Wilson and Hemmati-Brivanlou 1995). Interference with BMP signaling in ectodermal explants, by use of dominant-negative BM P ligands or receptors, results in the appearance of neural fate. In the ventral side of the ectoderm, where BMP signals remain active, the cells adopt an epidermal fate (for review, see Wilson and Hemmati-Brivanl ou 1997). BM P signal ing is also involved in patterning of the mesoderm, where it induces ventral fate; interfering with BM P signaling in the ventral side reveals the default dorsal fate of the mesoderm (for review, see Graff 1997). In this study we show that Smad6 can induce cement gland and neural tissues in ectodermal explants in a cell-autonomous and dose-dependent manner, without inducing mesoderm. Further- 
Hata et al.

A

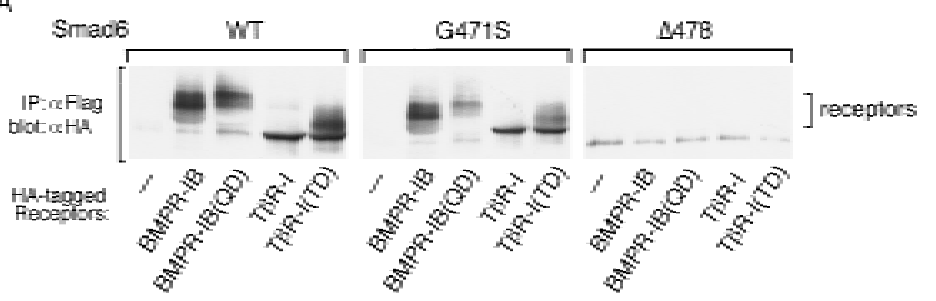

B

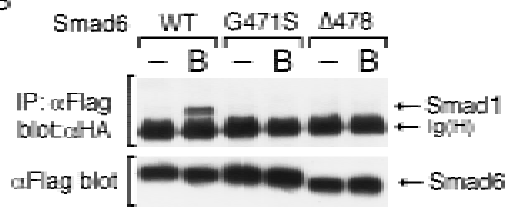

C
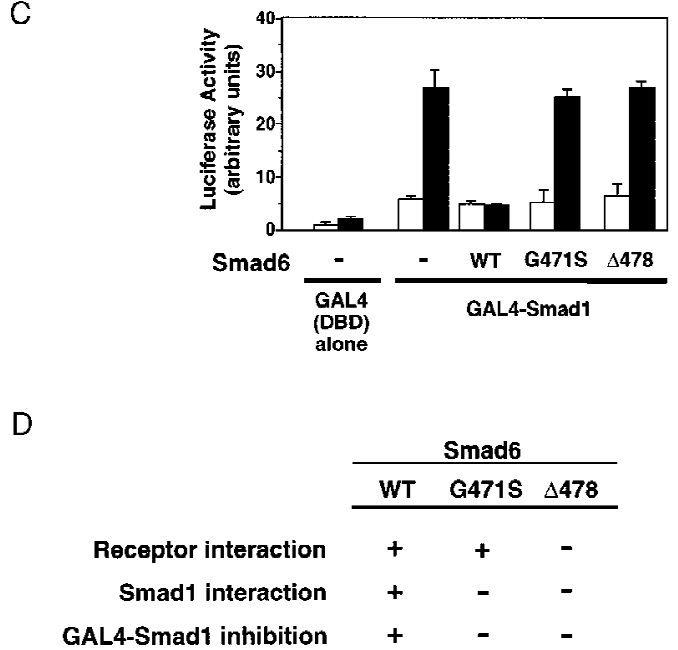

Figure 7. The inhibitory activity of Smad 6 segregates with its ability to interact with Smad1. (A) Smad6(G471S) interacts with the type I receptors of TGF $\beta$ family. Flag-tagged wild-type Smad6 (WT) or two different mutants (G471S and $\Delta 478$ ) were cotransfected into COS cells with HA-tagged wild-type or constitutively active type I receptor (QD and TD) for BM Ps (BM PR-IB) or TGF $\beta$ (T $\beta R$-I). Cell lysates were subjected to anti-Flag immunoprecipitation using a monoclonal antibody followed by immunoblotting using anti-HA polyclonal antibody. Similar levels of receptor and Smad6 expression were confirmed (data not shown). (B) Smad6 mutants fail to interact with Smad1 on BMP stimulation. Flag-tagged wild-type Smad6(WT) or mutants (G471S and $\Delta 478$ ) were cotransfected into COS cells with HA-tagged Smad1. Cell lysates were subjected to anti-Flag immunopreci pitation using a monocl onal antibody followed by immunoblotting using anti-HA polyclonal antibody (top panel). Similar levels of receptor and Smad6 expression were confirmed by anti-Flag Western blot (bottom panel). (C) Smad4 prevents Smad6 from inhibiting Smad1. R1B/L17 cells were transfected with the reporter gene (GAL4-Iux, $1 \mu \mathrm{g})$, BM PR-IB (1 $\mu \mathrm{g})$, BM PR-II $(0.1 \mu \mathrm{g})$ and either a vector containing the GAL4 DN A-binding domain (DBD) al one or a GAL4(DBD)-Smad1 fusion construct. Smad6 $(2 \mu \mathrm{g})$ and/or Smad4 $(4 \mu \mathrm{g})$ were cotransfected where indicated. Cells were incubated with (solid bar) or without (open bar) 5 nM BMP2 for $18 \mathrm{hr}$. Luciferase activity is expressed as the mean \pm S.D. of two independent experiments. (D) Summary table of the activities of Smad6 mutants.

more, Smad6 also inhibits induction of a ventral mesoderm marker by a BMP receptor. Similar effects were observed recently with Dad, a Drosophila homolog of Smad6 (T suneizumi et al. 1997).

Smad6 does not interfere with formation of the primary axis, a process that requires signaling via the activin receptor (Hemmati-Brivanlou and Melton 1992). When directly challenged by Smad6 in aXenopus animal cap assay, Smad1, but not Smad2, action was inhibited by Smad6. Furthermore, Smad6 antagonized BM P signaling in a GAL4 transcriptional assay in lung epithelial cells, but it did not antagonize TGF $\beta$ or activin in this assay or in a 3TP-lux reporter assay. Thus, Smad6 inhibits BM P/Smad1 signaling selectively, without inhibiting Smad2 signaling in Xenopus embryos or TGF $\beta$ and activin effects in mammalian cells. Smad6 may complement intracellularly the BMP inhibitory functions of $\mathrm{N}$ oggin, Chordin, or Follistatin and may play a key role in cell-autonomous determination of cell fate.

Smad6 as a Smad4 decoy: specific competition for receptor-activated Smad1

What mechanism accounts for the sel ective inhibition of the BM P/Smad1 pathway by Smad6? Our study suggests that Smad6 acts by inhibiting the formation of a Smad1Smad4 complex upon BMP receptor activation. Formation of this complex, which requires receptor-mediated phosphorylation of Smad1, is essential for Smad1 signaling (Lagna et al. 1996; Kretzschmar et al. 1997). Under our conditions, Smad6 inhibits the formation of this complex not by inhibiting Smad1 phosphorylation but by competing with Smad4 for receptor-activated Smad1 (Fig. 8). U pon BM P receptor activation, a Smad1-Smad6 complex is formed at the expense of Smad1-Smad4 complex formation. As with the Smad1-Smad4 interaction (Hata et al. 1997), a Smad1-Smad6 interaction directly mediated by the $\mathrm{C}$-domains of these proteins is detected in the yeast two-hybrid system. Thus, Smad4 and Smad6 may compete for overlapping binding sites in Smadl.

The selectivity of the Smad1-Smad6 interaction observed here is consistent with the specificity of the Smad6 anti-BMP effects and the ineffectiveness of Smad6 as an inhibitor of Smad2 signaling. Under our assay conditions, Smad6 does not interact with Smad2 in response to TGF $\beta$ in mammalian cells, or in a yeast twohybrid system. It was recently proposed that Smad7 inhibits TGF $\beta$ signal ing by binding to TGF $\beta$ receptors and inhibiting receptor-mediated Smad2 phosphorylation (Hayashi et al. 1997; Nakao et al. 1997). We observed that when overexpressed, Smad6 can interact indiscriminately with wild type, kinase-defective or activated mutant forms of type I receptors for BM P, TGF $\beta$, or activin. However, level s of Smad6 that are sufficient to block the Smad1-Smad4 interaction and signaling in mammalian cells do not inhibit BMP-induced Smad1 phosphoryla- 


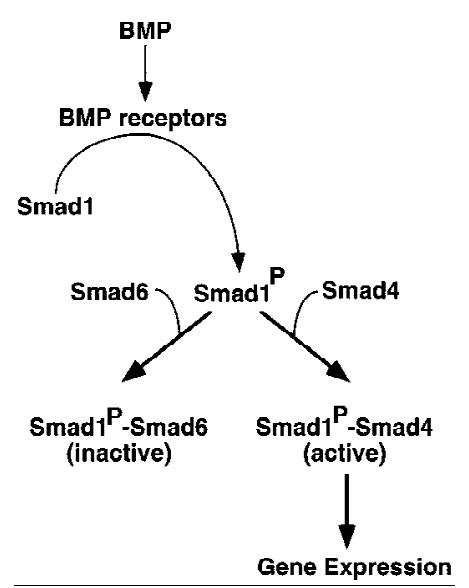

Figure 8. Proposed mechanism of action of Smad6. U pon phosphorylation by the BMP type I receptor, Smadl can interact with either Smad4 or Smad6. Although the Smad1-Smad6 complex is inactive, the Smad1-Smad4 complex triggers the expression of BM P responsive genes. The ratio between Smad4 and Smad6 in the cell can modulate the strength of the BM P signal.

tion. Furthermore, a Smad6 mutant (G471S) that binds to the type I receptors but does not bind to Smad1 no longer inhibits BMP/Smadl signaling. Thus, the interaction between Smad6 and type I receptors cannot account for the ability of Smad6 to specifically inhibit Smad1 signaling.

Recently, it was reported by Topper et al. (1997) and Imamura et al. (1997) that Smad6 can inhibit TGF $\beta$ signaling. However, the former study used the product of a Smad6 cl one identical to JV15-1 which, according to our unpublished observations, is expressed at very high levels ( 100-fold higher) when compared to full-length Smad6. At such levels, Smad6 may interfere with TGF $\beta$ receptor function. Like Imamura et al. (1997), we observed a reduction of Smad1 phosphorylation by Smad6 but only at concentration ratios of Smad6 to Smad1 10fold higher than those required to fully inhibit Smad1Smad4 association and signaling. The anti-receptor mechanism proposed by others might play a role in conditions of high Smad6 overexpression. The mechanism proposed here is more consistent with the ability of Smad6 to selectively inhibit BMP/Smadl signaling in Xenopus and mammalian cells.

By preventing the Smad1-Smad4 interaction, Smad6 would inhibit those BM P responses that depend on it. It is possible that Smad6 binding might direct the activated Smad1 to a different set of intracellular targets. However, we have no evidence that the Smad1-Smad6 complex has a separate signaling function. The effects that we have observed can therefore be attributed to the ability of Smad6 to function as a Smad4 decoy, generating inactive Smad1-Smad6 complexes in competition with Smad4 (Fig. 8). Smad6 may set a threshold that Smad4 must surpass to achieve signal propagation via Smad1. Because Smad6 does not associate with Smad2, the threshold imposed by Smad6 would not interfere with the TGF $\beta$ signal ing pathway. This and other Smad pathways may be controlled by separate antagonists perhaps related to Smad6.

\section{Materials and methods}

Cloning of human and Xenopus Smad6

The C-domain of human Smad6 (amino acids 272-496) was obtained by PCR amplification from a human liver CDN A library. Primers for the PCR were designed on the basis of the reported sequence for JV15-1 (Riggins et al. 1997). U sing this partial human Smad6 fragment as a probe, cDNA libraries made from human Jurkat cells (Clontech) and Xenopus tadpole head (Hemmati-Brivanlou et al. 1991) were screened. The human library yielded 12 independent clones that were isolated and sequenced. Except for some clones containing the Smad6 sequence fused to unrelated fragments, all of the cDN As encoded a 496-amino-acid protein (GenBank accession no. AF035528). Two Xenopus cDN As were found to encode mostly overlapping sequences corresponding to the last 276 amino acids of human Smad6 (GenBank accession no. AF035529).

\section{Construction of expression vectors}

Human Smad6(FL)/CS2, human Smad6(C)/CS2, and Xenopus Smad6(C)/CS2 were generated by subcloning the entire open reading frame or the $\mathrm{C}$-domain regions of human and Xenopus Smad6 (amino acids 272-496 of human Smad6) into a modified CS2 vector (Baker and Harland 1996; Turner and Weintraub 1994). Human Flag-Smad6(FL or C)/CS2 and HA-Smad6(FL or C)/CS2 were constructed from Smad6(FL or C)/CS2 by introducing the Flag or HA epitope tags at the amino terminus by PCR. The construction of Flag-Smad1/pCMV5, Flag-Smad2/ CS2, Flag-Smad4/CS2, Smad4-HA/pCMV5, pGAL4-Smad1, and pGAL4-Smad2 is described el sewhere (Lagna et al. 1996; Liu et al. 1996; Hata et al. 1997). Smad6 ( 4478 and G471S) was generated by a PCR-based method.

\section{Cell lines and transfections}

COS cells and R-1B/L17 cells were maintained in high-glucose Dulbecco's modified Eagle's medium supplemented with $10 \%$ FCS and minimal essential media containing 10\% FCS, respectively. For transi ent transfection, cells were seeded at 70\%-80\% confluency and were transfected with DEAE-dextran as described previously (Attisano et al. 1996).

In vivo phosphate labeling

For $\left[{ }^{32} \mathrm{P}\right]$ phosphate labeling, transiently transfected COS cells were washed and preincubated with phosphate-free media. The cells were then incubated with media containing $1 \mathrm{mCi} / \mathrm{ml}$ of ${ }^{32} \mathrm{P}$ ]phosphate for $2 \mathrm{hr}$ at $37^{\circ} \mathrm{C}$. Twenty minutes before the end of labeling, 100 pM TGF- $\beta$ or 5 nм BM P2 (a gift from V. Rosen, Genetics Institute, Cambridge, MA) was added. Immunoprecipitations and immunoblotting analyses were performed as described (Lagna et al. 1996).

Yeast two-hybrid system

The LexA-Smad6(C) (amino acids 272-496) fusion construct and GAL4 activation domain (GAD)-Smads fusions were created in pBTM 116 (Hata et al. 1997) and pGAD424 (Clontech), 
respectively. Interactions were tested by measuring $\beta$-galactosidase activity.

\section{Transcriptional assay}

R-1B/L17 cells were transiently transfected with $1 \mu \mathrm{g}$ of reporter plasmid (G1E1BCAT, GAL4-lux, or p3TP-lux), $0.1 \mu \mathrm{g}$ of BM PR-IB/BM PR-II,T $\beta R-I$, or ActR-IB, $0.5 \mu \mathrm{g}$ of the GAL4 derivatives (for GAL4 assay), and different amounts of Smad6/ CS2. Cells were treated with or without 100 pM TGF $\beta, 5 \mathrm{~nm}$ BM P2, or $2 \mathrm{nM}$ activin for $18 \mathrm{hr}$, and CAT or luciferase assay was performed as described before (Kretzschmar et al. 1997).

\section{Xenopus injections and animal cap assay}

RN As used for injections were synthesized in vitro in the presence of cap anal og using the $\mathrm{mM}$ essage $\mathrm{mM}$ achine kit (Ambion) and SP6 RNA polymerase. The DNA templates were obtained linearizing the corresponding pCS2 constructs with Ascl. For the induction of secondary axis, RNAs encoding Smads were coinjected with nuclear $\beta$-galactosidase RN A as described previously (Smith and Harland 1991). For the animal cap assay, RNA (10 nl, 0.5-4 ng) was introduced in the animal pole of two-cell embryos. A nimal caps were explanted at blastula stage and cultured to the indicated stage. RT-PCR was performed as described (Lagna et al. 1996).

\section{Acknowledgments}

We thank P. Wilson and D.C. Weinstein for critical reading of the manuscript, D. Wotton for help with the yeast two-hybrid system and J. Marden for technical assistance. We also thank the Genetics Institute for the BM P2 protein. N ational Institutes of Health grants to Memorial Sloan-Kettering Cancer Center (J.M. and A.H.-B.; HD32105-01) supported this work. A.H. is a research associate and J.M. an investigator of the Howard Hughes Medical Institute. A.H.-B. acknowledges support from the Searle, McKnight and Merck Foundations.

The publication costs of this article were defrayed in part by payment of page charges. This article must therefore be hereby marked "advertisement" in accordance with 18 USC section 1734 solely to indicate this fact.

\section{References}

Asashima, M., H. Nakano, K. Shimada, K. Kinoshita, K. Ishii, H. Shibai, and N. Ueno. 1990. Mesodermal induction in early amphibian embryos by activin A (erythroid differentiation factor). Wilhelm Roux's Arch. Dev. Biol. 198: 330-335.

Attisano, L., J.L. Wrana, E. Montalvo, and J. Massagué. 1996. Activation of signaling by the activin receptor complex. Mol. Cell. Biol. 16: 1066-1073.

Baker, J. and R.M. Harland. 1996. A novel mesoderm inducer, mM adr-2, functions in the activin signal transduction pathway. Genes \& Dev. 10: 1880-1889.

Chen, X., M.J. Rubock, and M. Whitman. 1996. A transcriptional partner of MAD proteins in TGF- $\beta$ signalling. Nature 383: 691-696.

Eppert, K., S.W. Scherer, H. Ozcelik, R. Pirone, P. Hoodless, H. Kim, L.-C. Tsui, B. Bapat, S. Gallinger, I.L. Andrulis, G.H. Thomsen, J.L. Wrana, and L. Attisano. 1996. MADR2 maps to $18 q 21$ and encodes a TGF $\beta$-regulated MAD-related protein that is functionally mutated in colorectal carcinoma. Cell 86: 543-552.

Graff, J.M. 1997. Embryonic patterning: to BMP or not to BMP, that is the question. Cell 89: 171-174.

Graff, J.M., R.S. Thies, J.J. Song, A.J. Cel este, and D.A. Melton. 1994. Studies with a Xenopus BMP Receptor suggest that ventral mesoderm-inducing signals override dorsal signals in vivo. Cell 79: 169-179.

Graff, J.M., A. Bansal, and D.A. Melton. 1996. Xenopus Mad proteins transduce distinct subsets of signals for the TGF $\beta$ superfamily. Cell 85: 479-487.

Hahn, S.A., M. Schutte, A.T.M.S. Hoque, C.A. Moskaluk, L.T. da Costa, E. Rozenblum, C.L. Weinstein, A. Fischer, C.J. Yeo, R.H. Hruban, and S.E. Kern. 1996. DPC4, a candidate tumor suppressor gene at human chromosome 18q21.1. Science 271: 350-353.

Hata, A., R.S. Lo, D. Wotton, G. Lagna, and J. Massagué. 1997. Mutations increasing autoinhibition inactivate tumour suppressors Smad2 and Smad4. Nature 388: 82-87.

Hayashi, H., S. Abdollah, Y. Qiu, J. Cai, Y. Xu, B.W. Grinnell, M.A. Richardson, J.N. Topper, M.A. Gimbrone, Jr., J.L. Wrana, and D. Falb. 1997. The MAD-related protein Smad7 associates with the TGF $\beta$ receptor and functions as an antagonist of TGF $\beta$ signaling. Cell 89: 1165-1173.

Hemmati-Brivanlou, A. and D.A. Melton. 1992. A truncated activin receptor inhibits mesoderm induction and formation of axial structures in Xenopus embryos. Nature 359: 609614.

Hemmati-Brivanlou, A., J.R. de la Torre, C. Holt, and R.M. HarIand. 1991. Cephalic expression and molecular characterization of Xenopus En-2. Development 111: 715-724.

Hemmati-Brivanlou, A., O.G. Kelly and D.A. Melton. 1994. Follistatin, an antagonist of activin is expressed in the Spemann organizer and displays direct neuralizing activity. Cell 77: 283-295.

Hogan, B.L.M. 1996. Bone morphogenetic proteins: multifunctional regulators of vertebrate development. Genes \& Dev. 10: 1580-1594.

Hoodless, P.A., T. Haerry, S. Abdollah, M. Stapleton, M.B. O'Connor, L. Attisano, and J.L. Wrana. 1996. MADR1, a MAD-related protein that functions in BMP2 signalling pathways. Cell 85: 489-500.

Imamura, T., M. Takase, A. Nishihara, E. Oeda, J. Hanai, M. Kawabata, and K. M iyazono. 1997. Smad6 inhibits signalling by the TGF- $\beta$ superfamily. Nature 389: 622-626.

Kretzschmar, M., F. Liu, A. Hata, J. Doody, and J. Massagué. 1997. The TGF- $\beta$ family mediator Smad1 is phosphorylated directly and activated functionally by the BMP receptor kinase. Genes \& Dev. 11: 984-995.

Lagna, G., A. Hata, A. Hemmati-Brivanlou, and J. Massagué. 1996. Partnership between DPC 4 and SMAD proteins in TGF $\beta$ signalling pathways. Nature 383: 832-836.

Lechleider, R.J., M.P. de Caestecker, A. Dehejia, M.H. Polymeropoulos, and A.B. Roberts. 1996. Serine, phosphorylation, chromosomal localization and TGF $\beta$ signal transduction by human bsp-1. J. Biol. Chem. 271: 17617-17620.

Liu, F., A. Hata, J. Baker, J. Doody, J. Cárcamo, R. Harland, and J. Massagué. 1996. A human Mad protein acting as a BM Pregulated transcriptional activator. Nature 381: 620-623.

Liu, F., C. Puponnot, and J. Massagué. 1997. Dual role of the Smad4/DPC4 tumor suppressor in TGF $\beta$-inducible transcriptional complexes. Genes \& Dev. 11: 3157-3167.

Macias-Silva, M., S. Abdollah, P.A. Hoodless, R. Pirone, L. Attisano, and J.L. Wrana. 1996. MADR2 is a substrate of the TGF $\beta$ receptor and phosphorylation is required for nuclear accumulation and signaling. Cell 87: 1215-1224.

Massagué, J., A. Hata, and F. Liu. 1997. TGF- $\beta$ signalling through the Smad pathway. Trends Cell Biol. 7: 187-192.

Massagué, J. and F. Weis-Garcia. 1996. Serine/threonine kinase 
receptors: M ediators of T GF- $\beta$ family signals. In Cancer Surveys (ed. T. Pawson and P. Parker), pp. 41-64. Imperial Cancer Research Fund, London, UK.

N akao, A., M . Afrakhte, A. M orén, T. N akayama, J.L. Christian, R. Heuchel, S. Itoh, M. Kawabata, N.-E. Heldin, C.-H. Heldin, and P. ten Dijke. 1997. Identification of Smad7, a TGF $\beta$ inducible antagonist of TGF- $\beta$ signalling. Nature 389: 631635.

N ewfeld, S.J., E.H. Chartoff, J.M. Graff, D.M. M elton, and W.M. Gel bart. 1996. Mothers against dpp encodes a conserved cytoplasmic protein required in DPP/TGF $\beta$ responsive cells. Development 122: 2099-2108.

Riggins, G.J., K.W. Kinzler, B. Vogelstein, and S. Thiagal ingam. 1997. Frequency of Smad gene mutations in human cancers. Cancer Res. 57: 2578-2580.

Sasai, Y., B. Lu, H. Steinbeisser, D. Geissert, L.K. Gont, and E.M De Robertis. 1994. Xenopus chordin: A novel dorsalizing factor activated by organizer-specific homeobox genes. Cell 79: 779-790.

Sasai, Y., B. Lu, H. Steinbeisser, and E.M. De Robertis. 1995. Regulation of neural induction by the Chd and Bmp-4 antagonistic patterning signals in Xenopus. Nature 376: 333336.

Shi, Y., A. Hata, R.S. Lo, J. M assagué, and N .P. Pavletich. 1997. A structural basis for mutational inactivation of the tumour suppressor Smad4. Nature 388: 87-93.

Smith, W.C. and R.M. Harland. 1991. Injected Xwnt-8 RN A acts early in Xenopus embryos to promote formation of a vegetal dorsalizing center. Cell 67: 753-765.

- - 1 1992. Expression cloning of noggin, a new dorsalizing factor localized to the Spemann Organizer in Xenopus embryos. Cell 70: 829-840.

Smith, J.C., B.M.J. Price, K. Van N immen, and D. Huylebroeck. 1990. Identification of a potent Xenopus mesoderm-inducing factor as a homologue of activin A. Nature 345: 729-731.

Suzuki, A., R.S. Thies, N. Yamaji, J.J. Song, J.M. Wozney, K. Murakami, and N. Ueno. 1994. A truncated bone morphogenetic protein receptor affects dorsal-ventral patterning in the early Xenopus embryo. Proc. Natl. Acad. Sci. 91: 1025510259.

Suzuki, A., C. Chang, J.M. Yingling, X.-F. Wang, and A. Hemmati-Brivanlou. 1997. Smad5 induces ventral fates in Xenopus embryo. Dev. Biol. 184: 402-405.

ten Dijke, P., K. Miyazono, and C.H. Heldin. 1996. Signaling via hetero-oligomeric complexes of type I and type II serine/ threonine kinase receptors. Curr. Opin. Cell Biol. 8: 139145.

Thomsen, G. 1996. Xenopus mothers against decapentaplegic is an embryonic ventralizing agent that acts downstream of the BM P-2/ 4 receptor. Development 122: 2359-2366.

Thomsen, G., T. Woolf, M. Whitman, S. Sokol, J. Vaughan, W. Vale, and D.A. M elton. 1990. Activins are expressed early in Xenopus embryogenesis and can induce axial mesoderm and anterior structures. Cell 63: 485-493.

Topper, J.N ., J. Cai, Y. Qiu, K.R. Anderson, Y. Xu, J. Deeds, R. Feeley, C. Gimeno, E. Woolf, O. Tayber, G. Mays, B.A Sampson, F. Schoen, M. Gimbrone, and D. Falb. 1997. Vascular MADs: two novel MAD-related genes selectively inducible by flow in human vascular endothelium. Proc. Natl. Acad. Sci. 94: 9314-9319.

Tsuneizumi, K., T. Nakayama, Y. Kamoshida, T.B. Kornberg J.L. Christian, and T. Tabata. 1997. Daughters against dpp modulates dpp organizing activity in drosophila wing development. Nature 389: 627-631.

Turner, D.L. and H. Weintraub. 1994. Expression of achaete scute homolog 3 in Xenopus embryos converts ectodermal cells to a neural fate. Genes \& Dev. 8: 1434-1447.

van den Eijnden-Van Raaij, A.J.M., E.J.J. van Zoelent, K. van Nimmmen, C.H. Coster, G.T. Snoek, A.J. Durston, and D. Huylebrock. 1990. Activin-like factor from Xenopus laevis cell line responsible for mesoderm induction. Nature 345: 732-734.

Watanabe, T.K., M. Suzuki, Y. Omori, H. Hishigaki, M. Horie, N . Kanemoto, T. Fujiwara, Y. N akamura, and E. Takahashi. 1997. Cloning and characterization of a novel member of the human M ad gene family (MADH6). Genomics 42: 446-451.

Wieser, R., J.L. Wrana, and J. M assagué. 1995. GS domain mutations that constitutively activate $T \beta R-I$, the downstream signaling component in the TGF- $\beta$ receptor complex. EMBO J. 14: $2199-2208$

Wilson, P.A. and A. Hemmati-Brivanlou. 1995. Induction of epidermis and inhibition of neural fate by Bmp-4. Nature 376: 331-333.

1997. Vertebrate neural induction: Inducers, inhibitors, and a new synthesis. Neuron 18: 699-710.

Wilson, P.A., G. Lagna, A. Suzuki, and A. Hemmati-Brivanlou. 1997. Concentration-dependent patterning of the Xenopus extoderm by BM P4 and its signal transducer Smad1. Development 124: 3177-3184.

Wu, R.-Y., Y. Zhang, X.-H. Feng, and R. Derynck. 1997. Heteromeric and homomeric interacions correlate with signaling activity and functional cooperativity of Smad3 and Smad4/ DPC4. Mol. Cell. Biol. 17: 2521-2528.

Xu, R.H., J. Kim, M. Taira, S. Zhan, D. Sredni, and H.F. Kung. 1995. A dominant negative bone morphogenetic protein 4 receptor causes neuralization in Xenopus ectoderm. Biochem. Biophys. Res. Commun. 212: 212-219.

Yingling, J.M., P. Das, C. Savage, C. Zhang, R.W. Padgett, and X.-F. Wang. 1996. M ammalian Dwarfins are phosphorylated in response to TGF- $\beta$ and are implicated in control of cell growth. Proc. Natl. Acad. Sci. 93: 8940-8944.

Zhang, Y., X.-H. Feng, R.-Y. Wu, and R. Derynck. 1996. Receptor-associated $\mathrm{M}$ ad homologues synergize as effectors of the TGF $\beta$ response. Nature 383: 168-172.

Zhang, Y., T. M usci, and R. Derynck. 1997. The tumor suppressor Smad4/DPC4 as a central mediator of Smad function. Curr. Biol. 7: 270-276.

Zimmerman, L., J. De Jesus-Escobar, and R. Harland. 1996. The Spemann organizer signal noggin binds and inactivates bone morphogenetic protein 4. Cell 86: 599-606. 


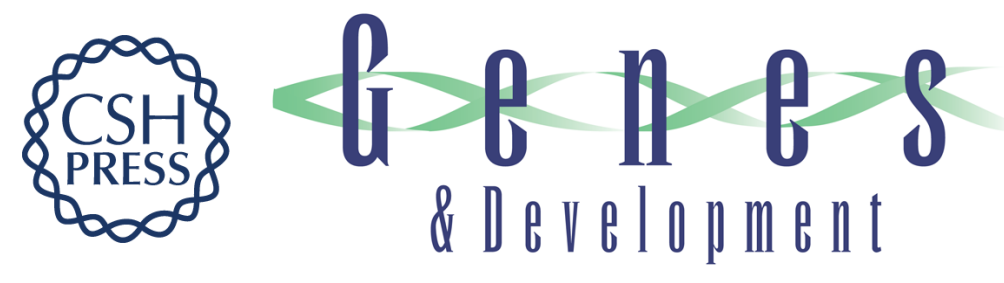

\section{Smad6 inhibits BMP/Smad1 signaling by specifically competing with the Smad4 tumor suppressor}

Akiko Hata, Giorgio Lagna, Joan Massagué, et al.

Genes Dev. 1998, 12:

Access the most recent version at doi:10.1101/gad.12.2.186

References This article cites 52 articles, 17 of which can be accessed free at: http://genesdev.cshlp.org/content/12/2/186.full.htmI\#ref-list-1

License

Email Alerting

Receive free email alerts when new articles cite this article - sign up in the box at the top Service right corner of the article or click here.

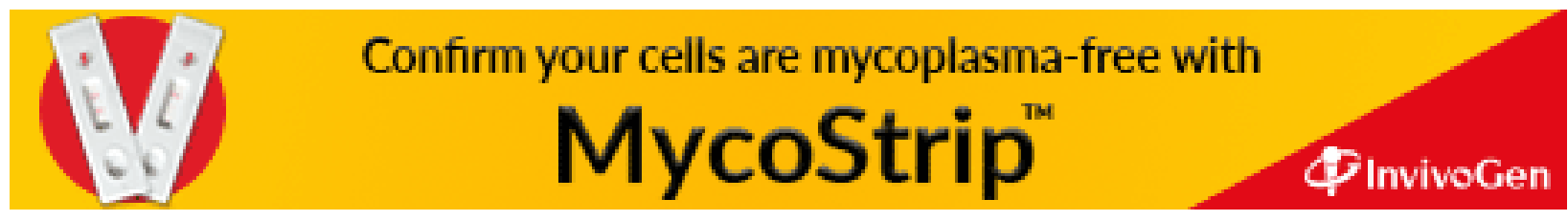

